
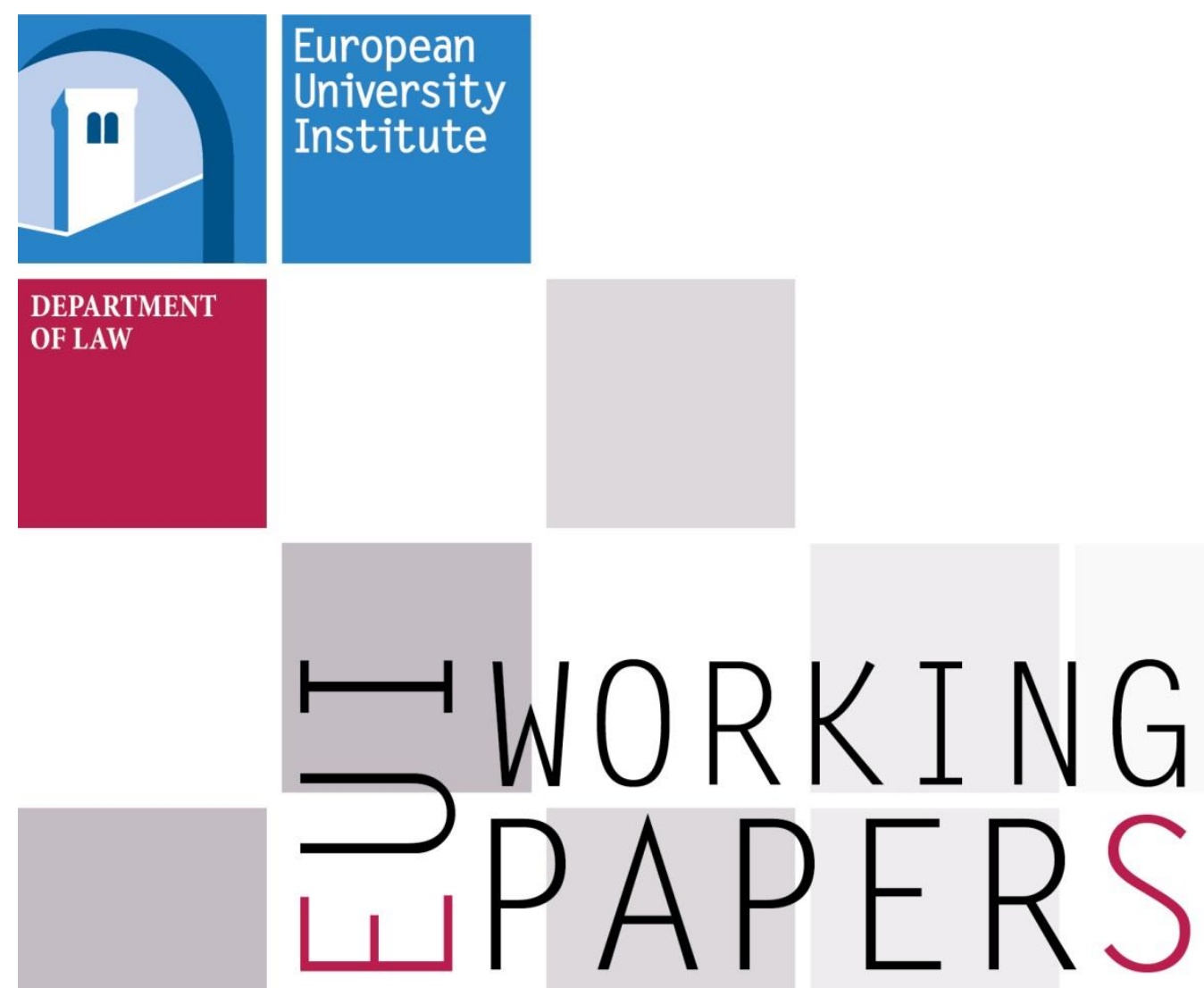

LAW 2015/23

Department of Law

A long way to a still-imperfect parity

Ana Espírito-Santo 

European University Institute Department of Law

\section{A LONG WAY TO A STILL-IMPERfect PARITY}

Ana Espírito-Santo

EUI Working Paper LAW 2015/23 
This text may be downloaded for personal research purposes only. Any additional reproduction for other purposes, whether in hard copy or electronically, requires the consent of the author. If cited or quoted, reference should be made to the full name of the author, the title, the working paper or other series, the year, and the publisher.

ISSN 1725-6739

(C) Ana Espírito-Santo, 2015

Printed in Italy

European University Institute

Badia Fiesolana

I-50014 San Domenico di Fiesole (FI)

Italy

www.eui.eu

cadmus.eui.eu 


\section{Legal Struggles and Political Mobilization around Gender Quotas}

This paper is part of a case study series stemming from a project, "Gender quotas in Europe: Towards European Parity Citizenship?" funded by the European University Institute Research Council and Jean Monnet Life Long Learning Programme under the scientific coordination of Professors Ruth RubioMarin and Eléonore Lépinard. Gender quotas are part of a global trend to improve women's representation in decision-making bodies. In the past decade they have often been extended in terms of the numbers to be reached ( 40 or $50 \%$ instead of $30 \%$ ), and in terms of the social field they should apply to (from politics to the economy to the administration). The aim of the project is to assess and analyse this global trend in the European context, comparing the adoption (or resistance to) gender quotas in 13 European countries in the fields of electoral politics, corporate boards and public bodies.

The case-studies in this series consider the legal struggles and political mobilization around Gender Quotas in Austria, Belgium, Denmark, France, Germany, Italy, Norway, Poland, Portugal, Slovenia, Spain, Sweden, and the U.K. They were presented and discussed in earlier versions at a workshop held in September 2014 at the EUI. Based on the workshop method, all working papers have reflected on similar aspects raised by their country case, concerning: 1) domestic/national preconditions and processes of adoption of gender quotas; 2) transnational factors; 3 ) legal and constitutional challenges raised by gender quotas in both the political and economic spheres; and 4) new frontiers in the field.

The working papers will be also made available on the blog of the workshop, where additional information on the experts and country information sheets can be found, and new developments can be shared. https://blogs.eui.eu/genderquotas.

This research has also been funded by Fundação para a Ciência e Tecnologia, Portugal, through the project Mulh(j)er e Poder: Women's Political Representation in Portugal and Spain (PTDC/IVC$\mathrm{CPO} / 4088 / 2012$ ). 

Author Contact Details

Ana Espírito-Santo

ISCTE-IUL (Lisbon University Institute)

Lisbon

Ana.Espirito.Santo@iscte.pt 


\begin{abstract}
In Portugal, gender quotas are (still) synonymous with gender electoral quotas. Those are the only quotas that really exist and they have been around for a long time. They have existed as party quotas since 1988 in the Socialist Party (PS) and as a statutory quota (Parity Law) since 2006. In the economic sphere, the first measure with some binding pressure aimed at achieving a more gender-balanced environment within state-owned companies was introduced in 2012. However, it is far from being considered a quota. This paper follows the conceptual model provided by Krook (2009) and seeks to expand previous work on the most important (f)actors that were involved in the Parity Law's adoption (Baum and EspíritoSanto, 2012). It does so by analysing a larger set of actors and by including an assessment of the actors involved in the first reforms in the economic sphere. This study is mainly based on a revision of the literature, but it also refers to two different sets of interviews with Portuguese MPs, which were conducted in 2005 and in 2014/2015.
\end{abstract}

\title{
Keywords
}

Gender quotas, Portugal, Parity Law. 


\section{Table of Contents}

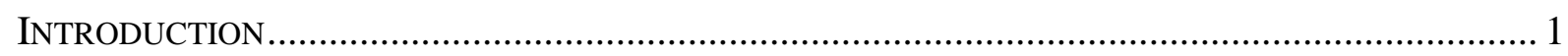

PRECONDITIONS AND PROCESSES FOR THE ADOPTION OF ELECTORAL GENDER QUOTAS .............. 1

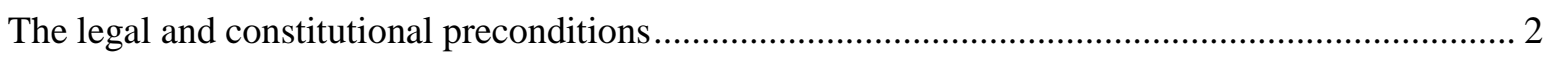

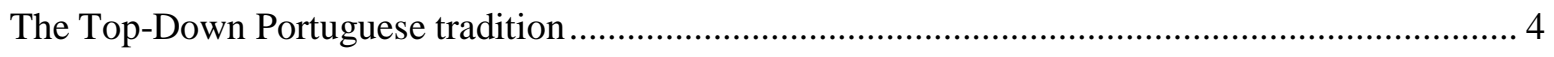

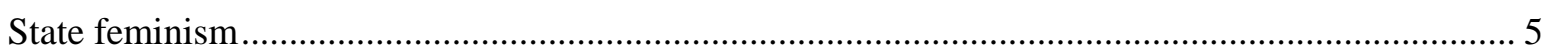

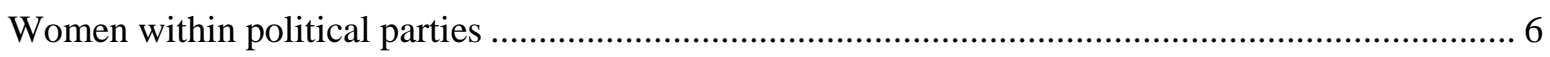

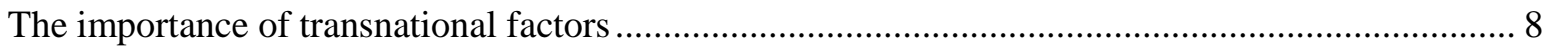

THE FIRST SHY STEPS INTO BINDING MEASURES IN THE ECONOMIC SPHERE …......................... 8

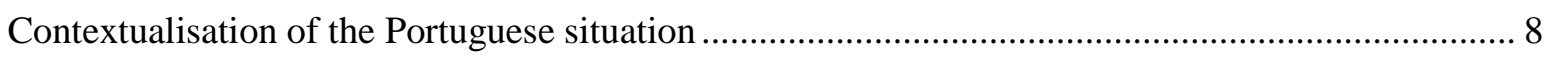

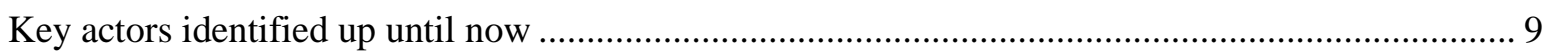

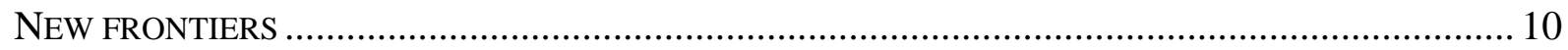

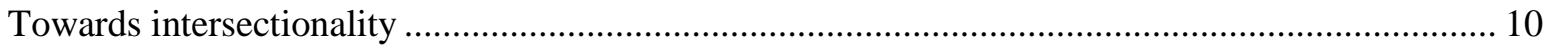

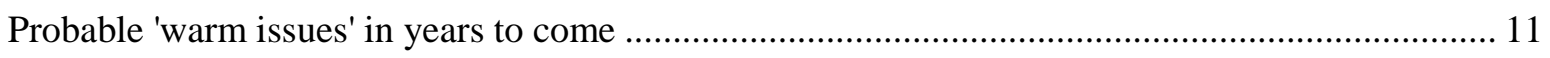

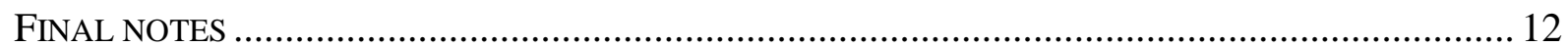





\section{Introduction}

In Portugal, a so-called, Parity Law ${ }^{1}$ was approved in August 2006. According to that law, all lists presented for local, legislative, and European elections must guarantee a minimum representation of $33 \%$ for each sex. Parties that do not respect this minimum are fined. The approval of that law places Portugal within a global trend for the adoption of such measures. That trend has been greatly intensified over the last 15 years, and at the moment, more than one hundred countries have gender quotas for political office (Franceschet et al., 2012: 3). Although political gender quotas are the oldest and by far the most common ones, two other generations (Holli, 2011) or groups (Meier, 2013) of gender quotas have recently appeared in several countries. These are gender quotas for advisory boards and gender quotas for boards of publicly listed and state-owned companies. This is not the case in Portugal, where gender quotas are (still) synonymous with gender electoral quotas. However, in 2012, the first measure with some binding pressure aiming at achieving a more gender-balanced environment within stateowned companies was introduced. Despite the fact that this measure is still far from being considered a quota (it is clearly a 'soft law'), it might constitute the first step in that direction.

My previous work with Michael Baum examined the most important (f)actors that were involved in the Parity Law's adoption (Baum and Espírito-Santo, 2012). This article expands that work by analysing a larger set of actors that were previously left out due to space restrictions and by including an assessment of the actors involved in the first steps into gender balance reforms in the economic sphere. This study is mainly based on a revision of the literature, but it also refers to two different sets of interviews with Portuguese MPs. The first set was conducted in 2005 (Espírito-Santo, 2006), just one year before the adoption of the electoral quotas law. The second set was conducted in 2014/2015, within the project Mulh(j)er e Poder, coordinated by Nina Wiesewomeier ${ }^{2}$ at the Institute for Social Sciences in Lisbon.

This paper follows more or less explicitly the conceptual model provided by Krook (2009), who identifies three categories of potential actors in quota campaigns in the literature: 1) civil society actors, such as women's movements and women's sections inside political parties; 2) state actors, such as national leaders and courts; and 3) international and transnational actors, such as international organisations and transnational non-governmental organisations (NGOs) (Krook, 2009: 20).

The paper is organised as follows. The next section 'Preconditions and processes for the adoption of electoral gender quotas' describes the role that the most important mobilising actors played in the adoption of electoral quotas. The third section, 'The first shy steps into binding measures in the economic sphere', pursues the same goal, but for the economic sphere. Section 'New Frontiers' reflects on some likely challenges of the years to come, and fifth section 'Final Notes' concludes by arguing which of the mentioned actors are more or less determinant.

\section{Preconditions and processes for the adoption of electoral gender quotas}

When we talk about gender quotas in Portugal, we are referring to electoral quotas. That is understandable, as those are the only quotas that really exist and they have been around for a long time. They have existed as party quotas since 1988 in the Socialist Party (PS), although they were in a latent status for one decade. In 1999, after the PS started complying with them, they also became part of the Portuguese political agenda. Between 1998 and 2006, several bills were proposed both by the PS and the Left Block $(\mathrm{BE})^{3}$ - the only two political parties that have pushed for the passage of the Parity Law. The three remaining parties with parliamentary representation - the Communist Party (PCP), the Social

\footnotetext{
${ }^{1}$ Organic Law no $3 / 2006,21^{\text {st }}$ August.

${ }^{2}$ http://mulherepoder.ics.ul.pt (accessed in January 2015).

${ }^{3}$ For an overview of all the bills introduced by the PS and the BE, see Baum and Espírito-Santo, 2012: 323.
} 
Democratic Party (PSD) and the Centre Democratic Christian-Popular Party (CDS-PP) - are all against quotas for different reasons.

However, it was only in 2006, when the PS had a majority in Parliament, that its bill ${ }^{4}$ and three bills from the $\mathrm{BE}^{5}$ passed on their general principles in the Assembly of the Republic with the support of all PS and BE MPs ${ }^{6}$. These four bills were very similar. All proposed the adoption of $33 \%$ minimum representation for each sex at all three levels (local, legislative, and European), and all used the word 'parity' in their titles as well as in their contents (Baum and Espírito Santo, 2012: 323). The use of the word 'parity' in both the bills and in the 2006 Portuguese quota law is puzzling, considering that they only require a minimum representation of $33 \%$ for each sex and not the $50 \%$ that is usually implied when the word 'parity' is used. In fact, the word 'parity' was used in all previous bills presented by both the PS and the BE, except for the first bill that each party presented (1998 for PS and 2001 for BE). The approval of a Parity Law (with this exact name) in France in June 2000 might have motivated the use of this expression in Portugal. In fact, the example of France is mentioned in the first bill that uses the word 'parity', which was presented in July 2000 by the PS 7

According to the exposition of motives of the bill presented by the PS in 2006, three main motives justify the adoption of such a measure, namely a) its contribution to the improvement of the democratic system, b) the question of justice and c) the idea that women's and men's different views of the world (due to historical and cultural reasons) complement each other. While the BE does not present the latter motive in its bills, it does use the previous two.

\section{The legal and constitutional preconditions}

In 1992, António Guterres was elected leader of the PS. Many interviewers, both in 2005 and 2014, referred to him as someone very committed to gender equality. In fact, in the 1992 Congress where he was elected, he put forward a motion expressing the under-representation of women in political power as a problem that should be solved (Espírito-Santo, 2006). The first legislative elections during Guterres' leadership took place in 1995, and that year was marked by an intensification of the PS party strategy concerning women's representation. From that year onwards, the PS officially assumed itself as a party engaged in increasing women's election by defending (for the first time in an electoral program) positive discrimination measures (p. I-5). More precisely, the PS manifesto for the 1995 legislative elections defended the 'approval of constitutional and legislative measures that promote, in an efficaciousness way, and equilibrium between men and women, in particular in their access to public and political positions' (p. I-6). Besides a clear to reference to the adoption of quotas, the previous sentence suggests a perception that the Constitution had to be revised before a law such as the current quota law could be approved.

The PS won the elections, Guterres became prime minister, and soon after, in 1997, the fourth revision of the Constitution took place ${ }^{8}$. However, it would be wrong to think that this revision was the result of the goal of the PS alone, which at the time had a relative majority of seats in Parliament (112/230). Revisions of the Portuguese Constitution 'require passage by a majority of two thirds of the Members

\footnotetext{
${ }^{4}$ Projecto de Lei 224/X, DAR II série A No.93/X/1 2006.03.11 (25-26).

${ }^{5}$ Projectos de Lei 221/X, 222/X, and 223/X, DAR II série A No.93/X/1 2006.03.11 (17-25).

${ }^{6}$ The president vetoed this version of the bill and therefore it was amended to include less stringent sanctions (see details on this in the next section). The BE abstained from voting for the new version of the bill (Baum and Espírito-Santo, 2012: 324).

${ }^{7}$ Proposta de Lei 40/VIII, DAR II série A No.59/VIII/1 2000.07.15 (1884-1891).

${ }^{8}$ So far, the Portuguese Constitution (which is from 1976) has been revised seven times: 1982, 1989, 1992, 1997, 2001, 2004, and 2005.
} 
of the Assembly of the Republic in full exercise of their office' (art. $286^{9}$ ); therefore, they can never be the result of the goal of a single party. Furthermore, the fourth revision consisted of a very vast and deep revision, which included 192 changes in total and comprised the modification of the numbering of more than 150 articles (Miranda, 28/07/2002). Hence, the amendments to the articles related to gender equality were only a small part of that revision and were considered as belonging to the minor issues (according to PS MP José Magalhães in a personal interview in January 2015). According to same MP (who was an MP at that time and had an active role in the revision of the Constitution ${ }^{10}$ ) the only reason why the PS decided to propose a revision of those articles more relevant to a possible quotas law was 'caution' and the wish to make the future (already planned internally ${ }^{11}$ ) process of proposing a quota law more fluid.

In the revised version of the Constitution, a new paragraph (h) was added to article 9 (Fundamental tasks of the State): 'To promote equality between men and women'. Another major legal change was on article 109 - Political participation by citizens of the Republic. In this article, the 'direct and active participation of citizens in political life', was changed to refer expressly to 'men and women'. That is, 'The direct and active participation of men and women in political life constitutes a condition and a fundamental instrument of consolidation of the democratic system and the law must promote equality in the exercise of the civic and political rights and non-discrimination in terms of gender regarding access to public positions'. This was a stepping stone, since it introduced the state's responsibility to promote equality in the political realm as a way to consolidate democratic principles. Also, this legal change potentially enables the state to advance special measures of positive discrimination to ensure women's political participation and access to public office (Espírito-Santo et al., 2007: $5^{12}$ ), so it left no space for potential arguments of unconstitutionality. On the contrary, it can be argued that as the Constitution stands at the moment, it could be unconstitutional not to have some kind of quota measure (Neto, 2010: 99).

When the bill that eventually became the Parity Law was approved in parliament, it was sent (following the normal legislative process) to the president of the Republic for enactment (Aníbal Cavaco Silva, affiliated with the PSD). Although opposition parties tried to persuade the president to nevertheless ask the Constitutional Court to study the constitutionality of the law, he decided not to do so (Baum and Espírito-Santo, 2012: 329).

However, the president did decide to veto that bill in June 2006 for other reasons. He considered the sanctions envisioned by the bill (i.e. the outright rejection of non-compliant party lists) as excessive. 'In his opinion, draconian punishment mechanisms would threaten both the freedom of the parties and the dignity of the women elected (DAR II série A No.120/X/1 2006.06.14, 2-3)' (Baum and Espírito-Santo, 2012: 329). Therefore, the bill was sent back to the Assembly and amended. The main amendments were: the imposition of fines on parties with non-compliant lists instead of the initial outright rejection of such lists and the insertion of an article requiring that the Parity Law be re-assessed in five years' time based on its impact on gender balance in Portuguese electoral politics. The bill passed again, although this time only with the support of the PS. The main reason for the BE's decision not to sign it was the less stringent sanctions. The new decree was promulgated by the president of the Republic in August 2006 and the Parity Law was published on 21 August 2006 (Baum and Espírito-Santo, 2012: 324).

\footnotetext{
9 Please find an English version of the current version of the Constitution here: http://www.en.parlamento. pt/Legislation/CRP/Constitution7th.pdf (accessed in January 2015)

${ }^{10} \mathrm{He}$ also has a PhD in Law, was involved in several revisions of the Constitutions and published books about the topic.

${ }^{11}$ In fact, in 1998 the PS introduced the first bill aiming at creating a more visible gender balance in national and European parliament, (Proposta de Lei 194/VII).

${ }^{12}$ For more information on this revision see: http://www.cne.pt/sites/default/files/dl/crp_1997.pdf (accessed in January 2015)
} 


\section{The Top-Down Portuguese tradition}

The process of adoption of a quota law in Portugal shares some similarities with the acquisition of women's suffrage in 1974. Although they both reflect the desires of women (or of some women, in the case of quotas), and despite the fact that there have been women involved in both cases, they are not direct consequences of a specific women's movement.

There is a great consensus around the idea that, once democracy was implemented in Portugal in 1974 after more than four decades (1926-1974) of a right wing dictatorial regime, universal suffrage came easily as a 'top-down' transformation ${ }^{13}$ (Amaral and Anjinho, 2012; Ferreira, 2011: 153). 'It was part of the package of measures deemed necessary for the construction of a modern state' (Ferreira, 2011: 153) and there seems to be a general agreement, even among activists interviewed by Ferreira (2011: 152-153), that the abolishment of all sexual inequalities in the law, including in the right to vote, came even before women requested it. That happened because there was no important mobilisation in defence of women's rights during the dictatorship (Ferreira, 2011: 153) and because, after four decades of Estado Novo, there were no feminist movements left in Portugal (Amaral and Anjinho, 2012).

It is nevertheless wrong to think that the promotion of women's rights came out of the blue, as many women participated in the struggle against the dictatorship (Ferreira, 2011: 153). Furthermore, Tavares argues that in the 1970s, there were actually many active organisations of women that pursued important interventions, namely concerning abortion and discrimination at work; however, only a few labelled themselves as feminist (2000: 116-117). Political parties dominated many of those organisations, especially those that occupied more public spheres, and that was one of the biggest obstacles to the development of autonomous women's organisations in Portugal (Ferreira, 2011: 186-187). Being feminist was not seen in a favourable light ${ }^{14}$ when the consensus was that there were other more urgent inequalities to solve. Nowadays, women's movements are no longer dominated by political parties, but they face other problems. They lack capacity for mobilisation and are very dependent on the state (see next subsection), which makes it hard for them to put pressure on those in political power and on the state (Ferreira and Monteiro, 2012: 19).

Although Portuguese civil society is comparatively weak overall, it is a fact that women's/feminist's associations have the lowest levels of membership among adults in Portugal (Fernandes, 2012: 3). These are followed by peace and environmental associations, whereas trade unions, sports/recreational, professional, and religious associations have more adherents (Fernandes, 2012: 9). This is the case because the salience of gender issues for Portuguese citizens is relatively low (Baum and Espírito-Santo, 2012) and it has been argued that there is no electoral market for gender policies in Portugal (Jiménez, 2009: 250). Abortion is the only gender-related issue that has had an impact on mobilising the Portuguese civil society (Espírito-Santo et al., 2007; Monteiro and Ferreira, 2012: 19-20 ${ }^{15}$ ). It is the only gender-related issue that can be considered a 'hot issue'16.

However, although the Portuguese population tends to be indifferent to gender issues (apart from abortion), it is not against gender quotas. A study conducted just one year before the adoption of the Parity Law shows that more than half of the nation favoured the implementation of a quota system in parliament (Martins and Teixeira, 2005). Most of the debate on gender quotas happened at the elite level and in the media, mainly after the PS introduced the first bill on the subject in 1998. Notwithstanding

\footnotetext{
${ }^{13}$ In November 1974, a new electoral law granted universal suffrage to both women and men for the first time in Portuguese history (Amaral and Anjinho, 2012).

${ }^{14}$ The violent reaction to the demonstration of the Movement for the Liberation of Women (MLW) on 13 January 1975 is very illustrative of this (see Ferreira, 2011: 184 for details on that episode).

${ }^{15}$ In Monteiro and Ferreira, there is a list of studies conducted on that subject (2012: 19-20).

${ }^{16}$ The debate on abortion started with the implementation of democracy in 1974 and became continually more intense until the adoption of a law (in 2007) that allows a voluntary interruption of a pregnancy in the first 10 weeks of pregnancy. But the issue of abortion clearly stands out as an outlier in regards to mobilising the civil society.
} 
its rejection, it contributed to increasing public exposure of this issue in Portugal (Jiménez, 2002: 293; Martins and Teixeira, 2005: 83; Viegas and Faria, 2001 : 51), but only at the elite level.

Seen from another perspective, the limited mobilisation of the civil society around electoral gender quotas was to be expected. If the adoption of a statutory quota law is to be seen as a reform of the electoral system (Celis et al., 2011), then the fact that the debate was undertaken mainly at an elite level is not surprising. Although there is a tendency towards an increasing impact of mass opinion upon changes in the electoral system (Renwick, 2011), in most cases, and certainly in Portugal, that debate takes place only at the elite level, namely, among political elites, the specialised academic community - sometimes called on by political parties to give their opinion - and the media.

What was the role of women's movements in the adoption of the electoral gender quota in 2006 ? We have argued elsewhere that although there was a mobilisation of some NGOs, they did not have a crucial role and that they were very influenced by transnational networks and actors (Baum and Espírito-Santo, 2012: 322). Three NGOs were visible in the media in favour of the adoption of the 2006 Parity Law: União de Mulheres Alternativa e Resposta (UMAR), the Portuguese Platform for Women's Rights (PPDM), and the Portuguese Network of Young People for Gender Equality (REDE). Their activities aimed mainly at increasing the public consciousness in terms of sexual discrimination in politics and not so much at putting direct pressure on political parties (Baum and Espírito-Santo, 2009). Aside from the separate actions of each NGO, there was also their official connection to the Portuguese women's policy agency, which was particularly important to the gender quota agenda. This is the subject of the next subsection.

\section{State feminism}

In the late twentieth century, women's policy agencies (WPAs) were created in several countries to take responsibility for the demands of women's movement activists (Lovenduski, 2005; Mazur and Stetson, 1995). 'These vary in scope, size, resources, stability, and location. They appeared at different times in different countries but are now part of the political landscape. Their existence is, at least in symbolic terms, an acknowledgement of women's demands for representation' (Lovenduski, 2005: 1).

In Portugal, the most important WPA has gone through several transformations. Since 2007, it has operated under the name, Commission for Citizenship and Gender Equality (CIG ${ }^{17}$; Law Decree 164/2007 of 3 May). This commission replaced the former Commission for the Equality and the Rights of Women (Comissão para a Igualdade e Direitos das Mulheres - CIDM), which had been in place since $1991^{18}$. Since the 1970 s, the Commission has contained an advisory board with two sections, the Interministerial one and the NGO one, where associations of women participate (NGO Section). The number of participating associations has been increasing significantly; whereas in 1975 it had 12 associations, in 2007 the number had increased to 54 (Monteiro and Ferreira, 2012: 16). Furthermore, between 1991 and 2002 (when important reforms happened), those organisations received an annual subsidy and were also given a meeting room in the CIDM's headquarters (Monteiro and Ferreira, 2012: 16) ${ }^{19}$. All this led to an institutionalisation of women's associations (Monteiro and Ferreira, 2012: 16), with those associations almost forgetting that they were part of civil society (Monteiro and Ferreira, 2012: 22), and to the previously mentioned lack of autonomy from the state.

\footnotetext{
${ }^{17} \mathrm{http}: / /$ www.cig.gov.pt (accessed in January 2015).

${ }^{18}$ At that time, it took the place of the Commission for the Feminine Condition (Comissão da Condição Feminina), which was set up in 1977, though it had already been in operation since 1973 (Espírito-Santo et al., 2007: 7).

${ }^{19}$ In 2002, reforms led to an increasing distance between the Commission and NGOs. The relationship between both parts began to follow more rules and became more formal. In 2005, for example, the room that the NGOs used to have in the Commission headquarters was taken away from them, which symbolically and physically implied the end of a close relationship (Ferreira and Monteiro, 2012: 22).
} 
Monteiro and Ferreira argue that in the second half of the 1970s, the Commission used to play an important role, since it participated in the process of decision-making several times and it had influence in the legislative content, i.e. in the quality of policy implementation (2012: 17) ${ }^{20}$. However, from the 1980s onwards, as the Commission gradually became more institutionalised, i.e. more a part of the state's bureaucracy, it also became more of a task performer than a proponent of policies (Monteiro and Ferreira, 2012: 21). Therefore, the role of the Commission has become mostly marginal and formative (Monteiro and Ferreira, 2012: 17). It is marginal in that, when the Commission tries to intervene in a certain political agenda (and actually does so through internal discussions, elaborating proposals, etc.), it does not manage to participate in the decision-making process because the system excludes it. It is formative in that the Commission's main goal is to increase the consciousness of both the public opinion and the political agents. So in the last decades, although the Commission and its networks of organisations have tried in different ways to influence decision-making, their role was blocked and limited by exogenous factors, namely by the political system (Monteiro and Ferreira, 2012: 17).

Concerning the adoption of the Parity Law, it would be unfair not to mention the effort of the Portuguese WPA and in particular of its NGO Section, since it was a long and persistent process (Monteiro, 2011). In the case of abortion, the lack of consensus among the women's associations present in the NGO Section led the Commission to abandon that agenda and to let each association act on its own (Monteiro and Ferreira, 2012: 20). However, in the case of gender quotas, since there was great consensus among all intervenients, the Commission got actively involved in this struggle. Monteiro argues that its symbolic action was decisive in promoting the importance of gender quotas among political agents (2011: 47). However, the same author mentions at least two crucial facts that illustrate the limits of the Commission's role in this agenda. Firstly, the fact that it was only called on to participate in a parliamentary debate on gender quotas in 1997-98, i.e. it was not part of the decision-making process (Monteiro, 2011: 41). Secondly, its influence in drafting legislative content was also limited, as can be seen by the fact that the law refers to a 33\% minimum presence of each sex, when the Commission had a clear preference for a real parity (50\%) (Monteiro, 2011: 38).

As a consequence of a reform the Portuguese WPA went through in 2007 (more on this in subsection: 'Towards intersectionality'), some associations that had always been part of the WPA's NGO Section were driven out, namely the trade unions and the political parties' women's departments (Monteiro and Ferreira, 2012: 23). The current absence of representatives of the political parties in the NGO Section could lead to the WPA possessing an even smaller ability to place pressure on those in political power. On the other hand, considering that the parties' women's departments are not very powerful, that might not necessarily be the case. The next subsection explores this topic further.

\section{Women within political parties}

'Evidence from many cases indicates that efforts to nominate more female candidates rarely occur in the absence of women's mobilisation' (Krook, 2009: 21). Portugal is not an exception to this statement. However, as we have seen so far, neither woman's associations nor its WPA were determinant in this track, despite the fact that they made some efforts in that direction. Who were, then, the determinant women? Female MPs interviewed in 2005 stated that most of the evolutionary processes their parties have experienced around women's issues can be attributed to the actions of (some) women from their parties, irrespective of these individuals' membership in women's departments (Baum and EspíritoSanto, 2012: 329): 'To this day within the BE, it is mainly women who push for feminist issues. And, depending on the specific issue, it might not be all women, but just some of them, even within the BE' (MP Helena Pinto, personal interview, 2005, in Espírito-Santo, 2006: 150). Socialist and Communist MPs pronounced similar sentences.

\footnotetext{
${ }^{20}$ For an overview of the specific laws for which the authors consider that the role of the Commission was relevant, please see Monteiro and Ferreira (2012: 17).
} 
The influence of women, both organised and not, is hard to prove due to its indirect character and the fact that most initiatives are carried out by men. An illustrative example of the difficulty to identify relevant actors is the PS's adoption of a party quota in 1988. Vitor Constâncio, who was the president of the PS at the time, proposed the adoption of this measure during the seventh party Congress, which was approved. However, it is unclear whether the idea was originally his or whether he was influenced by an individual woman or group of women within the party. Although he stated in a personal interview in 2005 that he was the one who thought of the idea, influenced by what was happening in other European countries (Espírito-Santo, 2006: 158), this seemed improbable, considering that, during the 1986 Congress, PS member Maria Belo put forward a motion officially raising this particular issue for the very first time (Baum and Espírito-Santo, 2012: 328-329). However, a personal interview with Maria Belo in January 2015 did exalt Vítor Constâncio as someone truly committed to gender equality and to quotas, whereas Belo - almost 30 years after presenting the referred pioneer motion ${ }^{21}$ - described herself as not so convinced that quotas are the best way to fight inequality. It is hard with this time distance to clearly understand what might have happened in the PS in the 1980s.

Krook warns us about the fact that 'stressing the support of women's groups has a tendency to gloss over the many women who oppose quota policies' (Krook, 2009: 21). This point is important because it perfectly fits the Portuguese case. Even within the PS (though not in the BE, at least to my knowledge), personal interviews in both 2005 and 2014 revealed that there are socialist female MPs who do not particularly like quotas. In a similar vein, although the official Social Democratic Party (PSD) position was (and still is) completely opposed to quotas, there are some PSD female MPs who agree with them, as was revealed in personal interviews both in 2005 and 2014. The current Secretary of State of Parliamentary Affairs and Equality, Teresa Morais, despite being a member of the PSD, is profoundly committed to gender equality and is a public defender of quotas (see section 'The first shy steps into binding measures in the economic sphere').

The three left-wing parties, namely the BE, the PS, and the Communist Party (PCP), all have internal women's organisations, either in the form of established departments (PCP and PS) or working groups (BE) (Baum and Espírito-Santo, 2012: 328). However, at least in the case of the PS - the most determinant party for the passage of the Parity Law - the women's department has a rather weak role. When asked in 2005 whether or not the women who are more involved in fighting for women's political presence within the party belong to the department, Socialist female MPs said that some do, whereas others do not (Espírito-Santo, 2006: 150). Also, more recent research has confirmed the finding (previously suggested by Monteiro, 2011) that the Socialist women's department is neither very renowned nor very influential within the party, since the most powerful women in the party prefer not to play an active role in it (Verge and Espírito-Santo, 2014). Furthermore, the department's strength and position (more feminist or more conservative) varies a lot depending on who the president is. Between 2003 and 2005, the president of the department (Sónia Fertuzinhos) was very feminist and deeply committed to gender quotas. When the PS introduced the proposal that eventually became the Parity Law in 2006, the president of the department was Manuela Augusto (2005-2011), who was described by a female Socialist MP in a personal interview in 2014 as someone who is for the female condition instead of for gender equality.

In conclusion, some women within the parties seem to have played crucial roles. Those women may or may not have belonged to the women's sections of their parties (which do not play big roles), but the most visible faces of the proposals were always men. This implies that these men had some sympathy towards these issues and had agreed to lend their voices to them. So, party leaders also play an important role here, even if it is not necessarily a mobilising one.

\footnotetext{
${ }^{21}$ And 20 years after having been the protagonist of symbolic moments such as the Paritarian Parliament in 1994 (Bettencourt and Silva Pereira, 1995).
} 


\section{The importance of transnational factors}

According to Krook, 'the actors that are most often overlooked are international organisations and transnational networks' (Krook, 2009: 17). And yet, they play a determinant role in the case of Portugal in several ways. In general, it can be said that the 'European directives and recommendations create a framework in which national policies and legislation must be elaborated' (Ferreira, 2011: 181). However, political parties and other actors are differently affected by international trends.

Interviews with female MPs conducted in 2005 pointed out the importance of the Socialist International (SI) and the Party of European Socialists (PES) - mainly the former - in the PS's decision to pursue the gender quota agenda. The type of contact the former organisation generates among the many social democratic parties that usually favour quotas has played at least some role in the way the party has evolved on this issue (Baum and Espírito-Santo: 2012: 330). Also, in 2003, the PS party quota was enlarged to one third of positions in party organs and electoral lists for either sex, following the call of Socialist International Women, which had urged affiliated parties to introduce or expand quota provisions (Verge, 2013: 445).

Concerning international organisations, Portugal has been affected primarily by three of them: the United Nations, the European Union, and the Council of Europe. This is visible in the fact that the evolution of the position of both the PS and the BE regarding the election of women followed closely the evolution of those three organisations (Baum and Espírito-Santo, 2012: 330-332). This can be confirmed through an analysis of the parties' strategies and, more directly, through the references to the international recommendations and guidelines contained in their electoral programs and most draft bills presented by both parties (Espírito-Santo, 2006). The latter seems to work as a legitimation or justification strategy.

Another point that demonstrates the relevance of transnational factors is that they are transversal to almost all actors somehow involved in the process of the adoption of gender quotas. First, they seem to be very inspiring for women's associations that are organised in international and European platforms. Second, there are some signs that party leaders may give them particular importance - see the previous subsection for the example of Constâncio, who states that what was happening in other European countries was important for his decision to propose a party quota in 1988. In summary, it is likely that transnational actors, along with some influential women within parties, are the actors that matter the most for convincing party leaders to be more proactive in gender equality issues.

\section{The first shy steps into binding measures in the economic sphere}

\section{Contextualisation of the Portuguese situation}

In October 2013, on average, $17.8 \%$ of the administrative boards of the biggest listed companies of the European Union were women, and $2.8 \%$ were presidents of the same companies. In Portugal, those values were significantly lower ( $8.8 \%$ and $0 \%$, respectively) (C.E., 201422: 3 quoted by Casaca, 2014: 175). Looking at these numbers, it is evident that there are grounds to justify the need for stronger measures in order to reach a more gender-balanced distribution of the highest positions in the economic sphere in Portugal. Nevertheless, up until now, only a few shy steps have been taken in that direction, demonstrating that the situation in the economic sphere is clearly different from the political sphere. The only measure with some binding pressure applied to state-owned companies in the area of gender equilibrium was accomplished through a Resolution of the Council of Ministers in 2012 (RCM n ${ }^{\circ}$

\footnotetext{
${ }^{22}$ C.E/E.C. (2014), 'Improving the gender balance in company boardrooms - proposal for a directive by de Commission on 14 November 2012', Factsheet, June.
} 
19/2012; ${ }^{23}$ Casaca, 2014: 194). That resolution can be said to have some binding pressure because it compels ('it determines compulsory') all state-owned companies to implement internal equality plans aiming at: a) reaching a de facto equality between women and men in the way they are treated and in the opportunities they have; b) eliminating all kinds of discriminations; and c) facilitating the conciliation between professional, familiar, and personal lives ( $\mathrm{RCM} \mathrm{n}^{\circ}$ 19/2012: 981).

However, the 2012 resolution might not be very efficacious for three reasons. The first one has to with the content of the binding pressure. The only thing it compels companies to do is to implement internal equality plans; it does not say anything about how demanding the objectives established in those plans should be. The second reason why I expect the resolution to have little success is that the document imposes no sanctions on non-compliant companies. Following the example of electoral gender quotas, the sanctions applied to non-compliance are crucial for the efficaciousness of the measure. The third reason is that a resolution does not have the weight of a law, so it is clearly different from the Parity Law in that sense. In fact, in 2013, another resolution (CMR n $\left.{ }^{\circ} 13 / 2013\right)$ appeared with very similar content (Casaca, 2014: 194-195), which suggests that the previous one was not too successful.

Neverthless, despite doing it in a very 'soft' way, the current centre-right government (2011-2015) seems determined to pursue this agenda. The last National Plan for Equality (V Plano Nacional para a Igualdade de Género, Cidadania e Não-discriminação 2014-2017) ${ }^{24}$, approved in 2013, has an innovative measure: the presence of women on the boards of directors is a criterion considered in the attribution of EU funds in the case of a tie (Casaca, 2014: 195). Considering how ineffective previous National Plans for Equality have been (Ferreira et al., 2010), no great success should be expected from this one either.

All this suggests that concerns with the position that women occupy in key positions of the economic sphere, along with specific measures to fight discrimination, are gradually taking space in the Portuguese political agenda, although in a very slow and inefficient way. Unless the UE launches a clear directive on this matter (which remains unclear at this point, Casaca, 2014: 191) ${ }^{25}$, it does not seem likely that Portugal will deepen this agenda much further. In the next subsection I try to explain the reasons for this.

\section{Key actors identified up until now}

For the shy steps that have been taken in order to achieve a better gender balance in key positions in the economic sphere, two key actors can be identified, a national one and a transnational one. The key national actor is the Secretary of State of Parliamentary Affairs and Equality Teresa Morais. I have interviewed her on a related project, and therefore I can attest how profoundly committed to gender equality issues she is, in contrast to her own political party. She is also publicly in favour of gender quotas, again marking a contrary position towards her party, which officially opposes them. Finally, she was the government spokesperson to the media every time each of the measures reported in the previous subsection was made public, suggesting that she is also the author of those measures.

In order to deal with gender inequalities in the economic sphere, the government collaborates with an important WPA called Commission for Equality in Labour and Employment (CITE) ${ }^{26}$. CITE is similar to the previously mentioned CIG, but it specialises in fighting discrimination and promoting equality between women and men, specifically in labour, employment, and vocational training.

\footnotetext{
${ }^{23} \mathrm{http}: / /$ www.cite.gov.pt/pt/destaques/complementosDestqs/RCM_19_2012.pdf (accessed in January 2015).

${ }^{24}$ https://dre.pt/pdf1sdip/2013/12/25300/0703607049.pdf (accessed in January 2015).

${ }^{25}$ In August 2014, the only measure at the UE level is a proposal for a Directive, which is being debated within the European Council. Only after an agreement is reached by the representatives of the member states and between the Council and the European Parliament will the proposal become a Directive (Casaca, 2014: 191).

${ }^{26} \mathrm{http}: / / w w w . c i t e . g o v . p t / e n / a b o u t \_u s . h t m l$ (accessed in January 2015).
} 
For the measure with some binding pressure previously mentioned (in RCM n ${ }^{\circ} 19 / 2012$ ), the UE appears as the most important motivation. Two reasons justify this statement. The first one is that references to this international actor are made in all of Teresa Morais' public interventions (as a justification for the measures adopted in Portugal), and also in the content of the resolutions previously mentioned (even with more evidence than what was previously reported in the case of gender electoral quotas). The second reason is the fact that the Portuguese government (in the person of Teresa Morais) reacted quickly to the challenge launched in May 2011 by Vice President of the European Commission Viviane Redding to European companies, aimed at motivating them to adopt self-regulatory measures to promote the equilibrium between women and men in their administrative boards (Call for self-regulation: women on the Board, Pledge for Europe , $^{27}$ Casaca, 2014: 186). Similarly, in 2012, Teresa Morais contacted the 20 biggest Portuguese companies to propose the same goal. Of those 20, only four had answered by March 2012, and their answers were negative ${ }^{28}$. This example shows not only how determinant the EU measures and attitudes are for what happens in Portugal, but also how the companies emerge as resisting actors.

In the case of gender quotas applied to the political sphere (see above), as an act of caution, the PS opted to revise the Constitution in order to make sure that no arguments of unconstitutionality could be raised in the advent of the proposal of a quota law. In contrast, no such amendments were made so far concerning the economic sphere. However, there are some articles in the Constitution that clearly defend the principle of gender equality. Besides the already mentioned paragraph (h) of article 9, article 13 (Principle of equality) should also not be forgotten. According to this article, 'no one may be privileged, favoured, prejudiced, deprived of any right or exempted from any duty for reasons of ancestry, sex (...)'. Furthermore, specifically concerning the economic sphere, the Constitution predicts that in order to ensure the right to work, the state is charged with promoting: (...) (b) equal opportunities in the choice of profession or type of work, and the conditions needed to avoid the gender-based preclusion or limitation of access to any position, work or professional category' (article 58). So there are several articles that could help to sustain the constitutionality of such a measure.

Moreover, according to the PS MP José Magalhães (in personal interview, as previously mentioned) the PS is currently (January 2015) preparing a bill to present in Parliament proposing gender quotas for big companies and he does not expect that that bill will face constitutional issues. However, the Constitutional principles are relatively undetermined and therefore their application to concrete cases is the object of many possible interpretations.

\section{New frontiers}

\section{Towards intersectionality}

Recent governmental options denounce a discrete move towards intersectionality. That is observable through the fact that the NGO Section of the CIG has been, since 2007, open to the presence of NGOs that deal with other inequalities, namely sexual orientation, transsexuality, religion, migration, and disabilities (Monteiro and Ferreira, 2012: 23). Also, the last two Global Plans for Equality, namely the IV (2011) and V (2013), are broader in scope than the three previous ones, as is immediately visible through the name. The first three plans were called 'National Plans for Equality - Citizenship and Gender', whereas from the IV plan onwards, the name became 'National Plan for Equality, Gender,

\footnotetext{
${ }^{27} \mathrm{http} / / /$ ec.europa.eu/commission_2010-2014/reding/pdf/p_en.pdf (accessed in January 2015).

${ }^{28} \mathrm{http}$ ://www.dnoticias.pt/actualidade/pais/311313-20-maiores-empresas-portuguesas-ignoraram-reforco-de-mulheres-emcargos-de-d (accessed in January 2015).
} 
Citizenship and Non-discrimination ${ }^{29}$. Finally, the parliamentary committee that deals with gender equality ${ }^{30}$ used to deal only with gender equality. However, at the moment, the respective committee is called 'Subcomission of Equality' and it deals with all kinds of equality issues - as stated by its president, Elza Pais, in a personal interview (2014).

However, when we look into the content of the approved measures, either the statutory quota law or the resolution for the economic sphere, there is only reference to gender. So, although there is a concern with intersectionality in theory, in practice, at least concerning gender quotas, women (vs. men) are considered a particular target.

\section{Probable 'warm issues' in years to come}

From what has been said up until now, it becomes expectable that the economic sphere will be the next salient issue to be dealt with in terms of gender quotas in Portugal. However, it is very likely that a long time will pass by before proper measures are implemented, if they are ever implemented at all. Irrespective of that, it will probably be part of the political agenda in the next years. The greater or lesser intensity will very much depend on the development of the agenda within the EU and on initiatives of political parties.

Concerning gender electoral quotas, their implementation has been quite successfully achieved apart from the local elections, where some problems remain. According to the Parity Law (article 4), noncompliance cases should be made public through the website for the National Commission of Elections. An analysis of the website shows that for local elections, non-compliance is common for all political parties. This was even true for the last local elections, which took place in September 2013. ${ }^{31}$ In several interviews, the difficulty of finding women available to integrate into the lists at the local level is mentioned. This difficulty has not been surpassed because the fines are paid by the party central office and therefore the local branches have not yet felt the direct consequences of non-compliance. Besides clear non-compliance, the media has reported several cases where women are located on the lists but quit their position immediately after the elections in order to give places to the following candidates on the list, who are always men.

However, the same did not apply to the European elections, where all parties fulfilled the law, or to the legislative elections, where only a few minor parties (without representation in parliament) disobeyed ${ }^{32}$. Concerning the national parliament, although the percentage of female MPs increased from $21.5 \%$ in 2005 (pre-quotas) to $27.8 \%$ in 2009 (and $26.5 \%$ in 2011), the level of success of the statutory quota is not very high since the level of feminisation of Parliament has never even reached the 33\%. In Portugal, the political parties only comply with the minimum requirements of the law - very seldom do the lists surpass the 33\% minimum requirement for women's presence. That is true even for the Socialist party, which had pushed for the Parity Law. In contrast to Spain, in Portugal the statutory quota blurred the differences between parties with different commitments to gender-balanced representation (Verge and Espírito-Santo, 2014).

\footnotetext{
${ }^{29}$ First Plan: http://www.dre.pt/pdf1sdip/1997/03/070b00/13231326.pdf; second: http://www.dre.pt/pdf1sdip/2003/11/273B00/80188032.pdf; third: http://www.dre.pt/pdf1sdip/2007/06/11900/39493987.pdf; fourth: http://www.cite.gov.pt/asstscite/downloads/IV_PNI_2011_2013.pdf and fifth: https://dre.pt/pdf1sdip/2013/12/25300/0703607049.pdf (accessed in January 2015).

30 There has not been such a committee in all legislatures. For example, between 2002 and 2009, it did not exist at all.

${ }^{31} \mathrm{http}: / / \mathrm{www} . \mathrm{cne}$.pt/content/eleicoes-autarquicas-2013 (accessed in January 2015).

${ }^{32}$ For example: http://www.cne.pt/content/eleicoes-para-assembleia-da-republica-2011 (accessed in January 2015).
} 
Concerning the European elections, the level of success is clearly higher. The feminisation of the Portuguese members of the European Parliament increased from 25\% in 2004 (pre-quotas) to $36.4 \%$ in 2009 , and to $38.1 \%$ in 2014.

There are nevertheless still a few challenges related to the electoral quotas. A potential future issue related to the electoral gender quota is the percentage of each sex that the Parity Law aims to achieve, i.e. 33\%. Some MPs from different parties who were interviewed in July 2014 have reported that, in some districts, the Parity Law works as a limitation rather than as a tool for increasing women's presence, i.e. as an excuse for parties to include only $33 \%$ women on their lists. However, all of them recognised that without quotas, fewer women would be placed on the lists of their parties, which constitutes a paradox. But the main challenge is that of the political positions that are not covered by the law. More importantly, those are usually the positions that contain the most power. This limitation was recognised by some socialist and feminist female MPs in personal interviews in 2014. In other words, although quotas do enable more women to get into politics, they are no guarantee that more women have power. Whether this concern, which is currently only shared by a small number of people, will reach a larger group in the near future remains an open question.

\section{Final notes}

This paper aims to assess the process of gender quota adoption in Portugal. It focuses mainly on electoral quotas, but it also looks at the first steps of what might one day become gender quotas in the economic sphere. The situation in each sphere is very different. There have been statutory electoral quotas in Portugal since 2006, whereas the only measure with some binding pressure related to the economic sphere (passed in 2012) is still far from being considered a quota. Furthermore, as it is an older debate, there are many more actors involved in the electoral quotas than in the potential quotas for companies. Political parties are an example of key actors that have not yet made public their position on the implementation of gender quotas for companies. Irrespective of these differences, the actors who mobilise to create gender quotas have some similarities. In addition, as argued in Krook (2009), in the case of Portugal, we observe that gender quotas are the result of multiple groups of actors.

In the case of both spheres, some key women within political parties were determinant, though there is a crucial difference. Whereas those women mainly remained in the background in the case of the electoral quotas, Secretary of State of Parliamentary Affairs and Equality Teresa Morais gave a face to the measures within the economic sphere. We will never know what would have happened if there was a centre-left party (PS) in government instead of the centre-right PSD, with the same European stimulus in place (i.e. with the same proposal being introduced by Vice President of the European Commission Viviane Redding). It is likely that stronger measures would have been implemented. However, the fact that a party that officially opposes quotas introduced legislation - although it was a 'soft' measure - in that direction suggests that the simple presence of a key strong person might trap the weight of ideology. It is important to add that both the PS and the PSD are catch-all parties and that, as mentioned before, gender issues are not considered important electoral issues in Portugal, neither by parties nor by the public. So, other societies might produce different outcomes.

The second determinant mobilising actor that applies to the measures adopted in both spheres is the transnational actors. There is a tendency in Portuguese society to value everything that comes from abroad, and that tendency is also visible in the way the country (and in particular the main parties) deal with measures towards gender equality. Referring to electoral structures, Celis, Krook and Meier (2011) wrote, quoting other authors, that in post-conflict societies and in developing countries, outside actors may play a larger role. These results suggest that the same could be said about post-dictatorial countries.

In contrast to the similarities found in the key mobilising actors for the approval of measures in both spheres, the main resisting actors differ completely. In the case of electoral quotas, the most important resistance came from the political parties that officially oppose quotas, from many male politicians (and 
some women) who disagree with quotas within the PS and the BE, and from the president of the Republic, who vetoed the first version of the bill after it had been approved in Parliament. In the economic sphere, the biggest opposition so far has come from the companies themselves that have basically ignored the government's appeals. Although these companies are likely to remain the biggest opponents to such measures, once this debate properly reaches the political agenda, other actors will define their public positions, namely political parties. 


\section{References}

Amaral ML and Anjinho T (2012) Winning Women's Vote: Female Suffrage in Portugal. In: RodríguezRuiz B and Rubio-Marín R (eds) The Struggle for Female Suffrage in Europe: Voting to Become Citizens. Leiden: Brill.

Baum M and Espírito-Santo A (2009) As Causas para a Adopção da Lei da Paridade em Portugal. In: Freire A and Viegas JML (eds) Representação Política: O Caso Português em Perspectiva Comparada. Lisbon: Sextante.

Baum M and Espírito-Santo A (2012) Portugal's 2006 Quota/Parity Law: an analysis of the causes for its adoption. West European and Politics 35: 319-342.

Bettencourt AM and Silva Pereira MM (1995) Mulheres Políticas - as suas causas. Lisbon: Quetzal Editores.

Casaca SF (2014) A Igualdade entre Mulheres e Homens e a Tomada de Decisão na Esfera Económica: o Longo Percurso dos Instrumentos Normativos. Revista do Centro de Estudos Judiciários 1: 173199.

Celis K, Krook ML and Meier P (2011) The Rise of Gender Quota Laws: Expanding the Spectrum of Determinants for Electoral Reform. West European Politics 34: 514-530.

Espírito-Santo A (2006) Para Além Das Cerejas: As Mulheres Nos Principais Partidos Políticos Portugueses (master thesis, unpublished). Lisbon: ISCTE.

Espírito-Santo A, Prata A and Fernandes IN (2007) Issue Histories Portugal: Series of Timelines of Policy Debates. Institute for Human Sciences (IWM), QUING Project. Available at: http://www.quing.eu/files/results/ih_portugal.pdf.

Fernandes T (2012) Civil Society after Dictatorship: A Comparison of Portugal and Spain, 1970-1990. Working paper 384. The Hellen Kellogg Institute for International Studies. Available at: https://kellogg.nd.edu/publications/workingpapers/WPS/384.pdf.

Ferreira V (2011) Engendering Portugal: Social Change, State Politics and Women's Social Mobilization. In: Costa Pinto A (ed) Contemporary Portugal - Politics, Society and Culture. 2nd ed. New York: Columbia University Press, 153-192.

Ferreira V, Silveirinha MJ, Portugal S, et al. (2010) Sumário Executivo do Estudo de Avaliação do III Plano Nacional para a Igualdade - Cidadania e Género. Available at: http://www.cig.gov.pt/wpcontent/uploads/2013/12/IIIPNI_Sumario_Executivo_4Nov2010.pdf.

Franceschet S, Krook ML and Piscopo JM (2012) The Impact of Gender Quotas. New York: Oxford University Press.

Holli AM (2011) Transforming local politics? The impact of gender quotas in Finland. In: Pini B and McDonald P (eds) Women and Representation in Local Government: International Case Studies. London and New York: Routledge, 142-158.

Jiménez AMR (2002) Mecanismos del cambio ideológico e introducción de políticas de género en partidos conservadores: el caso de AP-PP en España en perspectiva comparada. Madrid: Centro de Estudios Avanzados en Ciencias Sociales.

Jiménez AMR (2009) Women and decision-making participation within rightist parties in Portugal and Spain. Análise Social XLIV: 235-263.

Krook ML (2009) Quotas for Women in Politics: Gender and Candidate Selection Reform Worldwide. New York: Oxford University Press. 
Lovenduski J (2005) Introduction: State feminism and the political representation of women. In: Lovenduski J (ed) State Feminism and Political Representation. Cambridge: Cambridge University Press, 1-19.

Martins MM and Teixeira CP (2005) O Funcionamento dos Partidos e a Participação das Mulheres na Vida Política e Partidária em Portugal. Lisbon: CIDM.

Mazur A and Stetson D (1995) Comparative State Feminism. London: SAGE Publications.

Meier P (2013) Quotas, quotas everywhere: From party regulations to gender quotas for corporate management boards. Another case of contagion. Representation 49: 453-466.

Miranda J (28/07/2002) Acabar com o frenesim constitucional e debater a Europa. Público.

Monteiro R (2011) A Política de Quotas em Portugal: O papel dos partidos políticos e do feminismo de Estado. Revista Crítica de Ciências Sociais 92: 31-50.

Monteiro R and Ferreira V (2012) Metamorfoses das relações entre o Estado e os movimentos de mulheres em Portugal: entre a institucionalização e a autonomia. Ex aequo 25: 13-27.

Neto L (2010) Novos Direitos (Ou Novos Objectos para o Direito?). Porto: U. Porto Edições.

Renwick A (2011) Electoral Reform in Europe since 1945. West European Politics 34: 456-477.

Tavares M (2000) Movimentos de Mulheres em Portugal: Décadas de 70 e 80. Lisboa: Livros Horizonte.

Verge T (2013) Regulating gender equality in political office in southern Europe: The cases of Greece, Portugal and Spain. Representation 49: 439-452.

Verge T and Espírito-Santo A (2014) Gendered political recruitment after quota adoption in Portugal and Spain. ECPR Joint Sessions of Workshops. Salamanca.

Viegas JML and Faria S (2001 ) As Mulheres na Politica. Oeiras: Celta Editora. 
